\title{
ANALISIS MINAT BELAJAR KIMIA PESERTA DIDIK KELAS XII SMA NEGERI 6 YOGYAKARTA
}

\author{
Susi Anggorowati \\ Guru Kimia SMA Negeri 6 Yogyakarta \\ susi.anggorowati@gmail.com
}

\begin{abstract}
Abstrak
Penelitian ini bertujuan untuk menganalisis minat belajar kimia peserta didik kelas XII di SMA Negeri 6 Yogyakarta. Penelitian dilakukan menggunakan pendekatan kuantitatif dengan metode deskriptif . Teknik pengambilan sampel dilakukan secara random sampling dari kelas yang berbeda, sebanyak 123 peserta didik. Instrumen yang digunakan adalah angket tertutup sebanyak 30 item dengan empat alternatif pilihan. Aspek minat yang dikaji ada lima, yaitu peran guru, persepsi, kesenangan, kemauan dan penunjang UN pilihan. Data minat siswa dianalisis dan dikategorikan secara kuantitatif berdasarkan kriteria penilaian ideal. Hasil penelitian menunjukkan bahwa $3 \%$ peserta didik mempunyai minat belajar kimia sangat tinggi, 63\% tinggi, 32\% sedang dan 2\% rendah. Sedangkan peran guru menjadi aspek yang paling tinggi yaitu sebanyak $78 \%$, disusul aspek kemauan dan kesenangan yang mempunyai persentase yang sama yaitu $75 \%$. Selanjutnya aspek persepsi dengan perolehan $70 \%$, dan yang terendah adalah aspek penunjang UN pilihan sebanyak 69\%. Meskipun dari hasil penelitian secara umum minat belajar kimia peserta didik kelas XII SMA Negeri 6 Yogyakarta dalam kategori tinggi, namun masih perlu ditingkatkan lagi sesuai dengan aspek yang mempengaruhinya.
\end{abstract}

Kata kunci: Minat, Belajar Kimia, Peserta Didik SMA

\section{PENDAHULUAN}

Pendidikan merupakan kunci penting dalam proses pembangunan. Melalui pendidikan diharapkan mampu menciptakan manusia yang cerdas, kreatif, dan terbuka sehingga tujuan pembangunan nasional dapat tercapai. Kemajuan ilmu pengetahuan dan teknologi yang pesat menuntut sumber daya manusia yang berkualitas. Proses belajar mengajar adalah kegiatan utama dalam dunia pendidikan. Untuk mencapai keberhasilan dalam sebuah proses belajar dilihat dari hasil belajar yang optimal. Hasil belajar yang optimal salah satu faktor yang mempengaruhinya adalah minat belajar dari peserta didik. Minat sangat berpengaruh terhadap aktifitas belajar peserta didik. Peserta didik yang berminat terhadap pelajaran kimia akan mempelajari kimia dengan bersungguh-sungguh seperti rajin belajar, merasa senang mengikuti pembelajaran kimia, dapat 
menyelesaikan soal-soal latihan dan melakukan praktikum dengan baik dan benar. Peserta didik akan mudah menghafal pelajaran yang menarik minatnya. Menurut Gie (2004: 57) minat mempunyai peranan dalam "Melahirkan perhatian yang serta merta, memudahkan terciptanya pemusatan perhatian, dan mencegah gangguan perhatian dari luar”. Minat adalah suatu rasa lebih suka dan rasa keterikatan pada suatu hal atau aktivitas, tanpa ada yang menyuruh (Slameto, 2003: 180). Lebih lanjut Slameto (2003: 57) menjelaskan bahwa peserta didik yang berminat dalam belajar adalah sebagai berikut: 1) Memiliki kecenderungan yang tetap untuk memperhatikan dan mengenang sesuatu yang dipelajari secara terus-menerus. 2) Ada rasa suka dan senang terhadap sesuatu yang diminatinya. 3) Memperoleh sesuatu kebanggaan dan kepuasan pada suatu yang diminati. 4) Lebih menyukai hal yang lebih menjadi minatnya daripada hal yang lainnya. 5) Dimanifestasikan melalui partisipasi pada aktivitas dan kegiatan. Dari pendapat di atas dapat diketahui bahwa ciri-ciri minat belajar adalah memiliki kecenderungan yang tetap untuk memperhatikan dan mengenang sesuatu secara terus menerus, memperoleh kebanggaan dan kepuasan terhadap hal yang diminati, berpartisipasi pada pembelajaran, dan minat belajar dipengaruhi oleh budaya. Ketika peserta didik ada minat dalam belajar maka peserta didik akan senantiasa aktif berpartisipasi dalam pembelajaran dan akan memberikan prestasi yang baik dalam pencapaian prestasi belajar.

Observasi awal yang dilakukan dalam pelaksanaan pembelajaran kimia kelas XII di SMA Negeri 6 Yogyakarta, diperoleh bahwa keterlibatan peserta didik belum maksimal. Hal ini dapat terlihat dari kurangnya antusias peserta didik dalam mengikuti pembelajaran. Hanya beberapa saja yang mau bertanya terkait materi pelajaran yang kurang jelas. Keaktifan dalam diskusi dan mengerjakan soal-soal latihan juga masih kurang. Peserta didik terlihat pasif dengan hanya mendengarkan penjelasan guru. Belum optimalnya keterlibatan peserta didik tersebut menunjukkan minat belajar kimia yang masih rendah. Minat yang masih rendah juga terlihat dari sedikitnya peserta didik yang memilih kimia sebagai mata pelajaran pilihan dalam Ujian Nasioanal. Mulai tahun 2017 Kementerian pendidikan dan kebudayaan (Kemendikbud) membuat beberapa perubahan terkait pelaksanaan Ujian Nasional (UN). Salah satu yang berubah adalah jumlah mata 
pelajaran yang diujikan, dari 6 mata pelajaran berubah menjadi 4 mata pelajaran. Tiga mata pelajaran wajib, yaitu bahasa Indonesia, bahasa inggris dan matematika. Satu pelajaran boleh memilih sesuai jurusannya. Peserta didik dibebaskan untuk memilih sesuai dengan minat dan kemampuannya.Untuk jurusan IPA dapat memilih salah satu dari fisika, kimia atau biologi. Hal ini sesuai dengan Undang-Undang Nomor 20 Tahun 2003 tentang Sistem Pendidikan Nasional (Sisdiknas), Pasal 12 ayat 1 (b) bahwa setiap peserta didik pada setiap satuan pendidikan berhak mendapatkan pelayanan pendidikan sesuai dengan bakat, minat, dan kemampuannya. Pada tahun ajaran 2018/2019, tercatat baru $30 \%$ peserta didik yang mengambil kimia sebagai mata pelajaran pilihan pada Ujian Nasional (UN).

Minat belajar peserta didik dalam pembelajaran kimia dipengaruhi oleh banyak faktor yang dapat ditinjau dari komponen pembelajaran itu sendiri. Menurut Woolfok (2008) bahwa minat belajar peserta didik terutama dipengaruhi oleh karakter dari objek minat (mata pelajaran kimia), perasaan, serta lingkungan belajar. Setiap faktor mempunyai peran yang berbeda untuk tipa individu. Ada peserta didik yang minat belajarnya dominan dipengaruhi oleh perasaan atau persepsi awal tentang kimia, namun ada pula yang dominan dipengaruhi oleh lingkungan belajar. Sementara itu, Akram, Ijaz dan Ikram (2017) menyatakan bahwa faktor yang mempengaruhi minat belajar kimia siswa adalah kendala pribadi yang terutama bersumber dari kesulitan belajar yang ditemui, peran guru serta ruang lingkup pekerjaan professional yang berkaitan dengan kimia.

Hasil penelitian sebelumnya menunjukkan bahwa minat belajar kimia peserta didik dipengaruhi oleh sumber belajar dan konten yang diajarkan, persepsi siswa, serta strategi pembelajaran yang diterapkan (Boddey \& Berg, 2015; Huettel et al., 2013; Madhuri, Kantamreddi \& Goteti, 2012). Penelitian yang dilakukan oleh Haryanti dan Wiyarsi (2017) menunjukkan bahwa minat belajar kimia peserta didik paling tinggi dipengaruhi dari aspek peran guru. Penelitian terhadap minat belajar kimia peserta didik SMA Negeri 6 Yogyakarta menjadi perlu dilakukan melihat masih ada peserta didik yang kurang berminat. Analisis yang dilakukan juga menelaah faktor apa saja yang menyebabkan minat belajar 
kimia rendah. Dengan demikian dapat digunakan untuk memperbaiki proses pembelajaran sehingga minat belajar peserta didik menjadi semakin baik.

\section{METODE}

Penelitian ini menggunakan pendekatan kuantitatif dengan metode deskriptif. Variabel yang diukur adalah minat belajar kimia peserta didik kelas XII SMA Negeri 6 Yogyakarta. Penelitian dilakukan di SMA Negeri 6 Yogyakarta pada semester ganjil tahun pelajaran 2019/2020. Populasi penelitian adalah seluruh peserta didik kelas XII SMA Negeri 6 Yogyakarta sebanyak 228 peserta didik, sedangkan sampelnya sebanyak 123 peserta didik yang ditentukan secara acak (random sampling).

Data yang diambil dalam penelitian ini adalah data minat belajar kimia yang berupa skor (data kuantitatif). Data diperoleh dengan menyebarkan angket minat belajar kimia pada sampel peserta didik di awal tahun ajaran 2019/2020. Instrumen penelitian yang digunakan berupa angket tertutup dengan skala 4 yaitu sangat setuju (SS), setuju (S), kurang setuju (KS) dan tidak setuju (TS). Angket terdiri dari 30 pernyataan dengan 4 aspek yang dikaji yaitu peran guru (3 item), persepsi (4), kesenangan (8), kemauan (11) dan penunjang UN pilihan (4) yang dielaborasi dari teori minat dari Woolfolk (2009) dan hasil penelitian sebelumnya (Haryanti \& Wiyarsi, 2017 dan Akram, Ijaz \& Ikram, 2017).

Teknik analisis deskriptif tentang minat peserta didik ini dilakukan dengan langkah - langkah sebagai berikut.

1. Mengubah skor angket yang memiliki 4 alternatif jawaban yaitu sangat setuju, setuju, kurang setuju, tidak setuju. Pernyataan positif diberi skor 4,3,2,1 dan pernyataan negatif diberi skor 1,2,3,4.

2. Menghitung jumlah skor setiap kriteria.

3. Menghitung jumlah skor seluruh kriteria setiap aspek.

4. Menghitung skor rata - rata dari setiap aspek yang dinilai.

5. Skor terakhir setiap aspek maupun skor keseluruhan yang diperoleh dikonversi menjadi tingkat kelayakan secara kualitatif dengan pedoman konversi pada Tabel 1 sebagai berikut.

Tabel 1. Pedoman Kategorisasi

\begin{tabular}{lll}
\hline No & Rentang skor & Kategori \\
\hline
\end{tabular}




\begin{tabular}{clc}
\hline 1 & $\bar{X}>\mathrm{Mi}+1,8 \mathrm{Sbi}$ & Sangat tinggi \\
\hline 2 & $\mathrm{Mi}+0,6 \mathrm{Sbi}<\bar{X} \leq \mathrm{Mi}+1,8 \mathrm{Sbi}$ & Tinggi \\
\hline 3 & $\mathrm{Mi}-0,6 \mathrm{Sbi}<\bar{X} \leq \mathrm{Mi}+0,6 \mathrm{Sbi}$ & Sedang \\
\hline 4 & $\mathrm{Mi}-1,8 \mathrm{Sbi}<\bar{X} \leq \mathrm{Mi}-0,6 \mathrm{Sbi}$ & Rendah \\
\hline 5 & $\bar{X}<\mathrm{Mi}-1,8 \mathrm{Sbi}$ & Sangat rendah \\
\hline
\end{tabular}

Sumber : Widiyoko (2009)

\section{HASIL PENELITIAN DAN PEMBAHASAN}

\section{Kategori Minat Belajar Kimia Peserta Didik Kelas XII}

Hasil penelitian yang diperoleh bahwa minat belajar peserta didik kelas XII SMA Negeri 6 Yogyakarta secara keseluruhan termasuk dalam kategori tinggi. Rerata skor yang diperoleh sebesar 88,68 dari skor maksimal ideal 111. Sebaran kategori minat belajar kimia peserta didik dapat dilihat pada Gambar 1.

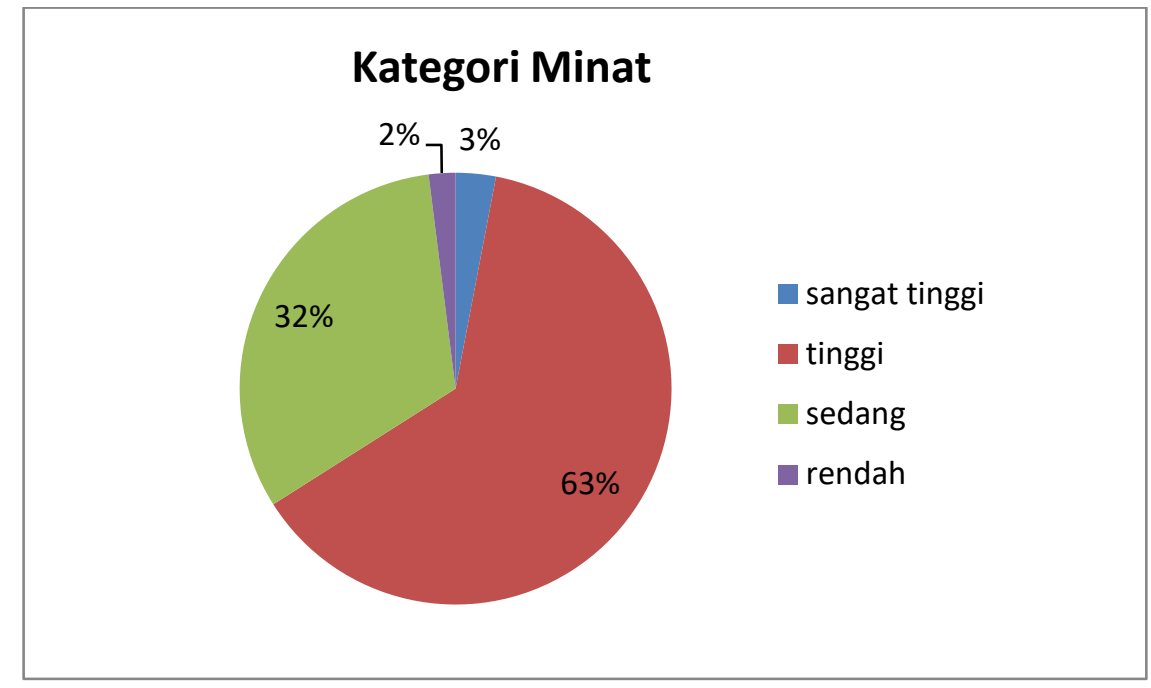

Gambar .1. Sebaran Kategori Minat Peserta Didik

Berdasarkan Gambar 1, diperoleh hasil bahwa sebanyak 3\% (4 peserta didik) mempunyai minat belajar kimia sangat tinggi, 63\% (77 peserta didik) mempunyai minat belajar kimia yang tinggi, 32\% (40 peserta didik) mempunyai minat belajar kimia yang sedang sedangkan 2\% (2 peserta didik) mempunyai minat belajar kimia yang rendah.

Walaupun dari hasil penelitian menunjukkan bahwa sebagian besar peserta didik mempunyai minat yang tinggi, tetapi kenyataannya pada saat pembelajaran kimia masih banyak peserta didik yang kurang memperhatikan dan tidak 
mengerjakan latihan yang diberikan dengan baik. Hal ini juga dapat dilihat dari masih banyaknya siswa yang tidak mengerjakan PR atau mengumpulkan tugas tepat pada waktu yang sudah ditentukan.

\section{Tinjauan Aspek Pendukung Minat Peserta Didik}

Analisis selanjutnya adalah dengan menghitung persentase pencapaian dari masing-masing aspek. Jumlah item tiap aspek tidak sama sehingga data hasil analisis ditampilkan dalam bentuk persentase pencapaian tiap aspek. Persentase pencapaian ini menunjukkan perbandingan rerata skor yang diperoleh dengan skor maksimal ideal untuk tiap aspek.

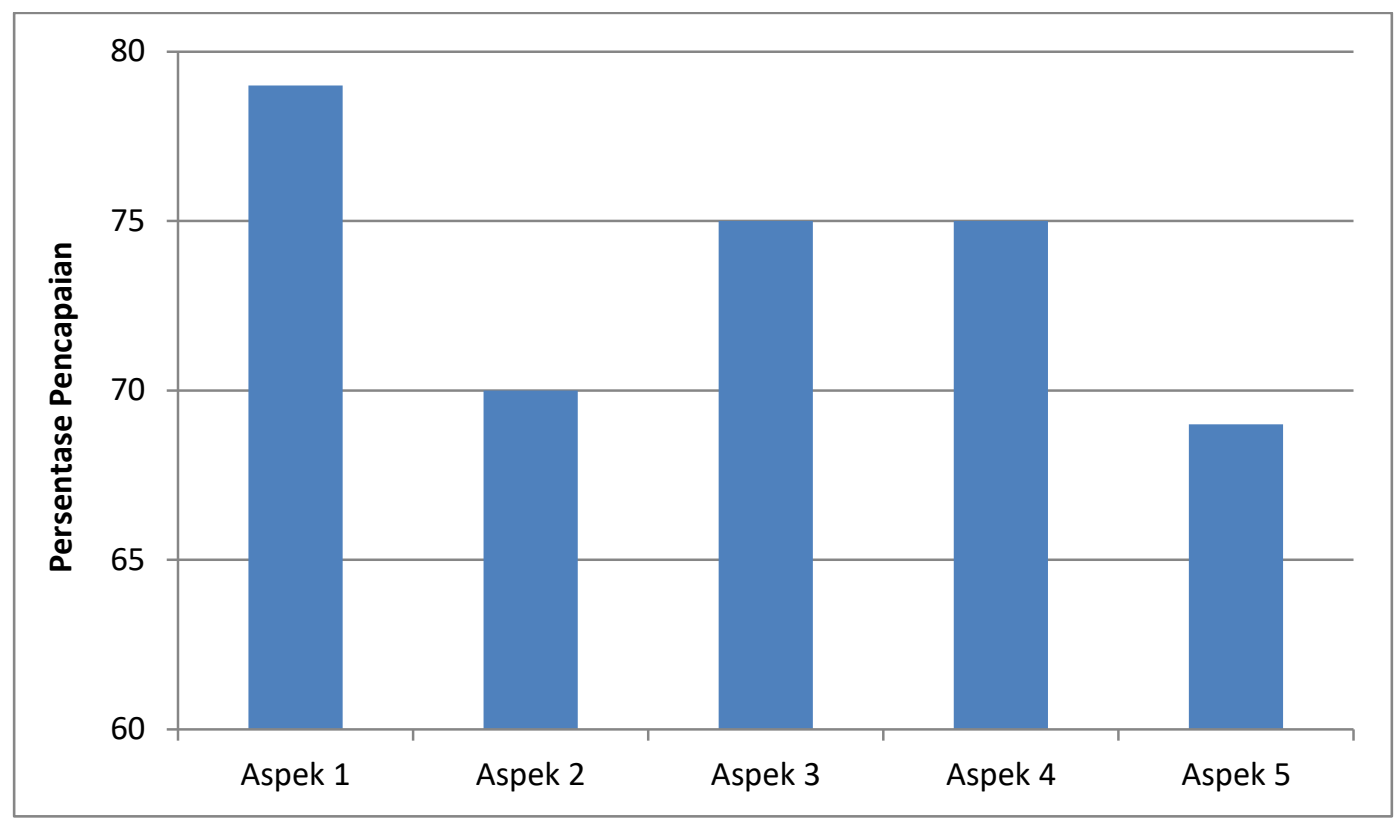

Gambar .2. Persentase Pencapaian pada Setiap Aspek yang Mempengaruhi Minat Belajar Peserta Didik

Keterangan:

Aspek 1 : Peran guru

Aspek 2 : Persepsi

Aspek 3 : Kesenangan

Aspek 4 : Kemauan

Aspek 5 : Penunjang UN pilihan 
Dari persentase pencapaian pada setiap aspek yang ditampilkan pada gambar 2, menunjukkan bahwa aspek 1 yaitu peran guru memperoleh persentase tertinggi yaitu sebesar 79\%. Peran guru ternyata sangat besar untuk menumbuhkan minat peserta didik belajar kimia. Hal ini sesuai dengan penelitian yang telah dilakukan Akram, Ijaz dan Ikram (2017) serta Haryanti dan Antuni (2017) yang menyatakan bahwa performance guru yang paling mempengaruhi minat belajar kimia siswa adalah kemampuan dalam menjelaskan materi di kelas dan menanyakan kesulitan atau memfasilitasi siswa untuk menanyakan bagian yang belum dipahami dengan baik. Peran guru diyakini sebagai faktor yang paling penting dalam tercapainya pembelajaran yang berkualitas (Karaman, 2012; Ghazi et al., 2013). Guru yang mengajar dengan metode yang tepat dan menyenangkan akan membuat peserta didik tertarik mempelajari kimia. Guru yang dengan penuh kesabaran menjelaskan dan membantu peserta didik dalam memahami materi kimia yang sulit juga akan berpengaruh terhadap minat peserta didik. Apabila ada peserta didik yang pada awalnya kurang berminat belajar kimia, dengan kesabaran dan perhatian dari guru akan membuat peserta didik menjadi senang belajar kimia.

Persentase tertinggi kedua adalah aspek 3 dan 4 dengan perolehan persentase yang sama yaitu sebesar 75\%. Aspek 3 adalah kesenangan dan aspek 4 adalah kemauan. Dua aspek ini cukup berpengaruh dalam menentukan minat peserta didik dalam belajar kimia. Apalabila peserta didik sudah senang dengan pelajaran kimia, maka dengan sendirinya keinginan untuk belajar tentulah besar. Ditambah lagi dengan adanya kemauan peserta didik untuk mempelajari kimia, sehingga akan berdampak pada pencapain hasil belajar yang maksimal.

Aspek berikutnya dengan persentase yang lebih rendah adalah aspek 2, yaitu persepsi. Persepsi ini berkaitan dengan pandangan peserta didik terhadap pembelajaran kimia. Pengalaman yang dialami oleh peserta didik bisa jadi faktor yang menyebabkan munculnya persepsi yang baik dan buruk dalam pembelajaran kimia. Pengalaman yang baik pada saat pembelajaran, seperti suasana belajar yang menyenangkan, guru yang penyabar dan perhatian. Hal ini dapat memunculkan persepsi yang baik terhadap pembelajaran kimia. Sebaliknya pengalaman yang buruk akan memunculkan persepsi yang buruk pula, seperti keyakinan yang selama ini berkembang bahwa kimia itu pelajaran yang sulit. 
Guru-guru yang mengajar kimia galak, pembelajarannya membosankan. Kemudian pada saat mengikuti pembelajaran kimia hal tersebut memang terjadi, sehingga nilai yang diperoleh rendah. Sudah barang tentu hal ini akan memunculkan persepsi yang buruk terhadap pembelajaran kimia. Oleh karena itu perlu dikembangkan pembelajaran yang baik dan menyenangkan, sehingga peserta didik akan tertarik dan senang belajar kimia. Selain itu peserta didik juga harus menanamkan dalam pikirannya bahwa kimia itu mudah dan menyenangkan, sehingga minat belajar kimia akan meningkat.

Persentase terendah yang mempengaruhi minat belajar kimia adalah aspek 5, yaitu penunjang UN pilihan. Peserta didik yang tidak mengambil kimia sebagai mata pelajaran pilihan di UN, ternyata tetap mempunyai minat belajar kimia yang baik. Namun memang sebagian besar peserta didik kelas XII belum menentukan mata pelajaran yang akan dipilih untuk UN. Mereka masih mempertimbangkan dan mengamati mata pelajaran mana yang dirasa pas dan paling tepat untuk mereka pilih.

\section{SIMPULAN}

Berdasarkan penelitian yang telah dilakukan dapat disimpulan bahwa minat belajar peserta didik kelas XII di SMA Negeri 6 Yogyakarta dikategorikan tinggi. Peran guru merupakan aspek dengan perolehan persentase tertinggi. Hal ini menunjukkan bahwa guru memberikan peran yang sangat penting dalam menumbuhkan minat belajar peserta didik. Sedangkan aspek penunjang UN pilihan merupakan aspek yang paling kecil perolehan persentasinya. Ini menunjukkan pula bahwa hanya sebagian kecil peserta didik yang berminat untuk mengambil UN pilihannya kimia. Untuk penelitian lebih lanjut dapat digunakan instrumen yang lebih bervariatif lagi sehingga data yang diperoleh lebih akurat untuk meningkatkan minat belajar kimia peserta didik.

\section{DAFTAR PUSTAKA}

Akram, T.M., Ijaz, A., \& Ikram, H. (2017). Exploring the factors responsible for Declining Students' Interest in Chemistry, International Journal of Information and Education Technology, 7(2), 88-94 
Boddey, K. \& Berg, K.d. (2015). The impact of nursing students' prior chemistry experience on academic performance and perception of relevance in a health science course, Chemistry Education Research and Practice, 16, 212-227.

Ghazi, S.R., Shahzada, G., Shah, M.T. \& Shauib, M. (2013). Teacher's professional competencies in knowledge of subject matters at secondary level in southern district of khyber pakhtunkhwa, pakistan. Journal of Educational and Social Research, 3 (2), 453-460.

Gie, T. L. (2004). Cara Belajar Yang Baik Bagi Mahasiswa. Yogyakarta: Gajah Mada Pers

Haryanti \& Wiyarsi, A. (2017). Analisis minat belajar kimia siswa kelas XI SMK Negeri 1 temon. Prosiding Seminar Nasional Kimia UNY 2017, Yogyakarta, 14 Oktober 2017, 67-73.

Huettel, L.G., Gustarfon, M.R., Nadeau, J.C., Schaad, D., Barger, M.M., \& Garcia, L.L. (2013). A grand challenge-based framework for contextual learning in engineering. Proceeding $120^{\text {th }}$ ASEE Annual Conference \& Exposition, Atlanta, 23-26 June 2013.

Karaman, A. (2012). The place of pedagogical content knowledge in teacher education. Atlas Journal of Science Education, 2 (1), 56-60.

Madhuri, G.V., Kantamreddi, V.S.S.N., \& Goteti, L.N.S.P. (2012). Promoting higher order thinking skills using inquiry-based learning. European Journal of Engineering Education, 37 (2), 117-123.

Slameto. (2003). Belajar dan faktor - faktor yang mempengaruhinya. Jakarta: Rineka Cipta

Undang-Undang No.20 Tahun 2003 tentang Sistem Pendidikan Nasional (Sisdiknas).

Widoyoko, S.E.P. (2009). Evaluasi Program Pembelajaran. Yogyakarta: Pustaka Belajar.

Woolfolk, A. (2009). Educational Psychology. Edisi asli terbit tahun 2008. Terjemahan Helly Prajitno \& Sri Mulyantini. Yogyakarta: Pustaka Pelajar. 